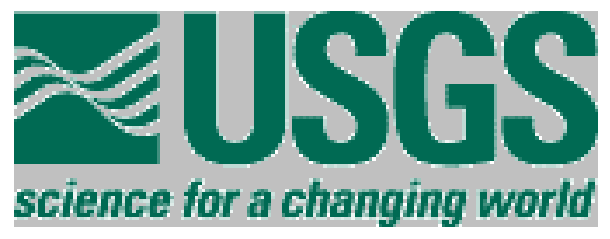

\title{
Mississippi Basin Carbon Project - Upland Soil Database for Sites in Nishnabotna River Basin, Iowa
}

\author{
by J.W. Harden, T. L. Fries, R. Haughy \\ U.S. Geological Survey, m.s. 962, 345 Middlefield Rd, Menlo Park, CA 94025
}

L. Kramer

National Tilth Laboratoratory, Agricultural Research Service, Council Bluffs, IA 51503

Shuhui Zheng

Dept. Earth System Science, University of California, Irvine, CA 92697-3100

This report is preliminary and has not been reviewed for conformity with U.S. Geological Survey editorial standards or with the North American Stratigraphic Code. Any Use of trade, product, or firm names is for descriptive purposes only and does not imply endorsement by the U.S. Government 
Table of Contents:

(as text format)

1.00 Background

1.10 Objectives

1.20 Approach

1.3 Land use background

2.00 Methods

2.10 Field Methods

2.20 Sample Preparation and Drying

2.30 Total Carbon, Inorganic carbon, Organic Carbon, Total Nitrogen, ${ }^{13} \mathrm{C},{ }^{15} \mathrm{~N}$

2.40 Radiocarbon

2.50 Particle Size Analysis

$2.60{ }^{10} \mathrm{Be}$ Analsyis

3.00 Data-set Identification

3.10 Labling Schemes

3.20 Data Set Descriptions

3.21 Iowa_Site files

3.22 Iowa_Field

3.23 Iowa_Soil

3.24 Iowa_C_Isotope

3.25 Iowa_Psize

3.26 Iowa_10Be

4.00 Application of Data Set

5.00 References

6.00 Investigators

7.00 Acknowledgements

List of figures.

Figure 1. Location of study areas........... Fig.1

List of tables (as separate downloadable files)

Table 1. Site Description................... Iowa_Site

Table 2. Descriptive Field Data ........... Iowa_Field

Table 3. Soil Analytical Data .............. Iowa_Soil

Table 4. Particle Size Data ................ Iowa_Psize

Table 5. Soil Carbon Isotopic Data........ Iowa_C_Isotope

Table 6. Beryllium Isotopic Data ......... Iowa_10Be 


\subsection{BACKGROUND}

The conversion of land from its native state to an agricultural use commonly results in a significant loss of soil carbon (Mann, 1985; Davidson and Ackerman, 1993). Globally, this loss is estimated to account for as much as $1 / 3$ of the net $\mathrm{CO}_{2}$ emissions for the period of 1850 to 1980 (Houghton and others, 1983). Roughly 20 to 40 percent of original soil carbon is estimated to be lost as $\mathrm{CO}_{2}$ as a result of agricultural conversion, or "decomposition enhancement". Global models use this estimate along with land conversion data to provide agricultural contributions of $\mathrm{CO}_{2}$ emissions for global carbon budgets (Houghton and others, 1983; Schimel, 1995).

Soil erosion rates are significantly (10X) higher on croplands than on their undisturbed equivalents (Dabney and others, 1997). Most of the concern over erosion is related to diminished productivity of the uplands (Stallings, 1957; McGregor and others, 1969; Rhoton, 1990) or to increased hazards and navigability of the lowlands in the late 1800's to early 1900's. Yet because soil carbon is concentrated at the soil surface, with an exponential decline in concentration with depth (Harden et al, 1999), it is clear that changes in erosion rates seen on croplands must also impact soil carbon storage and terrestrial carbon budgets as well.

As yet, erosional losses of carbon are not included in global carbon budgets explicitly as a factor in land conversion nor implicitly as a portion of the decomposition enhancement. However, recent work by Lal and others (1995) and by Stallard (1998) suggests that significant amounts of eroded soil may be stored in man-made reservoirs and depositional environments as a result of agricultural conversion. Moreover, Stallard points out that eroding soils have the potential for replacing part of the carbon trapped in man-made reservoirs. If true, then the global carbon budget may grossly underestimate or ignore a significant sink term resulting from the burial of eroded soil.

\subsection{OBJECTIVES}

A primary goal of the Mississippi Basin Carbon Project (Sundquist and others, 1998) is to define simple, functional relationships between hillslope erosion/sedimentation and soil organic matter dynamics. To meet this goal, small watersheds (Huntington and others,1998) were chosen for studies of upland soils in context of and collaboration with ongoing erosion/sedimentation studies. Our strategies for site selection and sampling approaches are described by Harden and others (1998, 1999 and in press).

The study sites are located in watersheds of the Nishnabotna River Basin in western Iowa (Fig. 1). The agricultural sites are located within the an experimental watershed, which has been maintained by U.S. Department of Agriculture (USDA) Agricultural Research Service (ARS) under the auspices of the Deep Loess Research Station (DLRS) near the town of Treynor. The cultivated sites are located within watershed 1-1 (watershed 1, sub-basin 1) of the DLRS. The undisturbed 
USGS MBCP-U Document text

prairie sites, used as control sites, are located near the town of Harlan in a small parcel of land referred to as the Dinesen Prairie, which is owned by USDA Natural Resources Conservation Service (NRCS) and is maintained by Iowa's Department of Natural Resources. All soils of this study are developed on Peoria Loess (Bettis, 1990; Muhs and Bettis, 2000;), which is a postglacial deposit that thins westward of its origin at the Missouri River.

In this report we present soil analytical data for the Dineson Prairie (control) and Treynor (cropland) sites. Field and analytical methods are described herein in text format, and data are

presented as downloadable ASCII text from the internet site http://geochange.er.usgs.gov/usgs/mbcp/.

\subsection{APPROACH}

As discussed in Harden and others, 1998 for a similar sampling campaign in the state of Mississippi, a sampling strategy was designed to allow for stratification of soil data by depth, slope position, and cultivation history. Soil samples were collected at ridgetop, erosional midslope ("upper") and depositional lower slope ("lower") positions of small drainage basins for cultivated and uncultivated landuse pairs. Documentation and data sets described in this report include (1) site location, (2) descriptive field data, (3) physical, chemical, and isotopic analysis of (solid phase) soil samples, and (4) isotopic analysis of soil gas collected from static field chambers. A companion report by Huntington and others (in prep) provides soil respiration and soil climate data at these sites. Another companion report by Manies and others (2000) provides parameterization strategies for running the Century ecosystem model and provides documentation for the landuse history of these sites.

\subsection{LAND USE HISTORY}

Details of tilth, fertilization, and historic erosion are documented in detail by Manies and others (2000). Dinesen Prairie was chosen as a control site because it is uncultivated, unplowed, and representative of the original, pre-agricultural soil. At the Treynor cropland site, rotations of cornwheat or corn-oat-clover were used from 1870 to 1964, followed by corn from 1964 to 1996 with conventional tillage. In 1997, soybeans were planted in the watershed using no-till drill methods. The switch from 30 years of corn to 2 years of soybean provides an opportunity for an isotopic tracer study.

\subsection{METHODS.}

\subsection{FIELD METHODS.}

Soil profiles were described according to USDA-NRCS methods (Soil Survey Staff, 1951) in which a variety of field properties were recorded for soil horizons at different depths. Properties 


\section{USGS MBCP-U Document text}

such as soil color, consistence, texture, structure, root size and density were recorded on field sheets and transferred to data sets.

The mass of soil organic carbon and total $\mathrm{C}$ per unit land surface area is referred to as the carbon inventory of a site. Measurements of percent organic C, bulk density and depth are included in these data. The calculation of carbon inventory is depth-dependent and can be measured or calculated to $0.5 \mathrm{~m}, 1 \mathrm{~m}$, or greater depths. Most of MBCP-Upland measurements include data to $1 \mathrm{~m}$ depths.

Soil samples were collected such that volumetric data could be combined with gravimetric data to provide measurements in units of volume (3 dimensional), area (2 dimensional), and depth (1 dimensional). Bulk density, field moisture content, and depth increments are included in soil sampling. Bulk density samples were collected with a variety of tools, including cores of known diameter (mineral soil) or boxes (litter and organic horizons) of known area. Samples were collected into the core or box of known volume. Our most consistent and accurate density measurements for Iowa soils were obtained with a coring device by Soil Moisture Corporation that we named "whomper" in which internal rings can be disassembled for intact samples. Less consistent and less accurate measurements were obtained from a hand-driven soil AMS core with internal sleeves; we found that a slighly crimped tip on the commercial core gave densities comparable to "whomper". The revised tip of the AMS probe was mainly at the Dinesen Prairie where we were careful to not disturb the rare and fragile soil and at both Treynor and Dineson for incubation and fractionation samples (0-20 and 20-40 cm depth increments). For deep samples at both Treynor and Dinesen, we used a Giddings automated, truck mounted coring device, which yielded bulk density values in close agreement with the "whomper" method. As separate samples or as portions of the bulk density samples, gravimetric samples were collected for analysis of $\mathrm{C}, \mathrm{N}$, isotopic analysis, and moisture content. Profiles were sampled at depth intervals of 0-5, 5-10, 10-20, and every $20 \mathrm{~cm}$ below a depth of $20 \mathrm{~cm}$. Maximum depth of samples vary from about 200 to $300 \mathrm{~cm}$. Volumetric and gravimetric samples were weighed on collection day on a calibrated balance to $0.01 \mathrm{~g}$. The weights of moisture samples were then tracked throughout air-drying and oven-drying to determine moisture content and bulk density based on air and oven-dry weights.

Samples of soil gas were collected through a soil chamber that was connected with a LICOR gas analyzer. These sites were monitored seasonally for soil $\mathrm{CO}_{2}$ flux, by $\mathrm{T}$. Huntington (Huntington and others, in prep). For soil ${ }^{14} \mathrm{CO}_{2}$ and ${ }^{13} \mathrm{CO}_{2}$, the soil chamber was placed into a sand ring that was confined between two pieces of PVC rings (see Huntington and others, 1998). The chamber was "scrubbed" by placing a soda lime trap (along with a dessicant to protect the soda lime) in line with the circulating air for a period of time (1000 to $3000 \mathrm{sec})$ that allowed approximately 2.5 to 3 volumes of chamber air to pass through the soda lime. This way, only a small fraction (about $5 \%$ to $10 \%$ ) of $\mathrm{CO}_{2}$ in circulating chamber air was likely to be contributed from the atmosphere, leaving the majority (90 to 95\%) of $\mathrm{CO}_{2}$ to be respired from roots and soil heterotrophs. After "scrubbing" the chamber gas with soda lime, a valve was used to close the soda 


\section{USGS MBCP-U Document text}

lime trap. For radiocarbon samples, we allowed $\mathrm{CO}_{2}$ to build up in the soil chamber; a valve was then used to trap soil $\mathrm{CO}_{2}$ onto molecular sieve material for determination of ${ }^{14} \mathrm{C}$ and ${ }^{13} \mathrm{C}$.

Samples of soil gas were also collected for ${ }^{13} \mathrm{C}$ of $\mathrm{CO}_{2}$ using the LICOR gas analyser and in-line glass vials. In this method, the chamber was placed in the PVC/sand ring. While the vial was in line with circulating soil air, soil $\mathrm{CO}_{2}$ was allowed to build up in the vial and chamber for about 6 minutes (collection time noted) before closing the vial. We compared this method to ${ }^{13} \mathrm{C}$ obtained from scrubbing and trapping onto the molecular sieve and found the results to be very similar (data not shown).

\subsection{SAMPLE PREPARATION AND DRYING}

Field notes were used to inventory all samples entering the laboratory. Samples were visually inspected and weighed as received. Any inconsistency between field descriptions or weights and laboratory observations was resolved before sample preparation began. If samples taken for analytical, moisture or bulk density measurements could not be processed immediately they were stored in the dark, at $4{ }^{\circ} \mathrm{C}$.

Soil and litter samples were laid out on open shelves, in an isolated room and allowed to air dry to a constant weight. Temperature in the air drying room ranged from $20-30{ }^{\circ} \mathrm{C}$ during this process. Air dry moisture samples, or portions of air dry samples, were then oven dried to constant weight in a forced-draft oven. Litter samples, as well as any other samples that appreared to contain greater than 20 percent organic matter, were oven dried at a temperature of $65^{\circ} \mathrm{C}$ to avoid loss of organic matter by oxidation or decomposition. All other samples were oven dried at a temperature of $105^{\circ} \mathrm{C}$. Air-dry and oven dry weights from this procedure were used in the calculations of percent moisture and bulk density.

To prepare air dry soil samples for analysis the samples were first gently crushed using a ceramic mallet and plate. The crushed sample material was thoroughly mixed and then split into analytical and archive portions. The analytical portion was weighed and sieved using a $2 \mathrm{~mm}$ screen. Material not passing the $2 \mathrm{~mm}$ screen was removed, weighed and transferred to a plastic bag marked with the sample identification, the starting weight of the analytical portion and the weight of the material not passing through the $2 \mathrm{~mm}$ screen. Material passing the $2 \mathrm{~mm}$ screen was then ground by hand, using a mortar and pestle, to pass through a 60 mesh $(0.246 \mathrm{~mm})$ screen. The ground material was carefully mixed, then split into subsamples for oven drying, analytical chemistry and archiving. Portions of the sample, such as large sections of bark or large diameter $(>1 \mathrm{~cm})$ material, were placed in separate bags and included with the archive portion. The analytical portion of the air dry litter sample was prepared for analysis by first manually chopping or crushing larger material and then milling the entire sample to pass a $0.5 \mathrm{~mm}$ screen using a cyclone sample mill. The milled sample was then thoroughly mixed and a representative sample placed in a labeled, glass sample bottle. 


\section{USGS MBCP-U Document text}

The archive portions of the litter, $60 \mathrm{mesh}$, and $0.5 \mathrm{~mm}$ sample were placed in labeled, plastic bag for storage. For litter samples, the bags used for storage were large enough that the entire air-dry archive portion could be placed in the bag without crushing the sample. Archive materials were then boxed for storage at the U.S. Geological Survey District Office, 3039 Amwiler Rd. Atlanta, GA. All excess sample materials and waste were oven dried at $120^{\circ} \mathrm{C}$ for 72 hours prior to disposal as per U.S. Dept. Agriculture guidelines for sterilization and soil disposal.

2.3 TOTAL CARBON, INORGANIC CARBON, ORGANIC CARBON, TOTAL NITROGEN, AND ${ }^{13} \mathrm{C},{ }^{15} \mathrm{~N}$

Total percent carbon (TC) was determined by measuring the carbon dioxide $\left(\mathrm{CO}_{2}\right)$ produced by combusting the sample in a stream of oxygen $\left(\mathrm{O}_{2}\right)$. Total carbon measurements were made using either a LECO carbon determinator (WR-112) or a Fisons NA1500 elemental analyser(EA)/ Optima isotope ratio mass spectrometer (IRMS). Percent inorganic carbon (IC) was determined by measuring the $\mathrm{CO}_{2}$ generated by heating a sample at $105{ }^{\circ} \mathrm{C}$ in acid. A UIC coulometer was used for this measurement. Percent organic carbon was calculated as the difference between TC and IC. A Fisons NA1500 EA/Optima IRMS was also used for the determination of total nitrogen and for ${ }^{15} \mathrm{~N}$ and ${ }^{13} \mathrm{C}$ measurements.

Total carbon measurements made using the LECO carbon determinator were carried out by analyzing between 0.1 and $1.0 \mathrm{~g}$ of sample, depending on expected carbon concentration. The sample material was mixed with copper metal and iron chip accelerators in a ceramic crucible, the ceramic crucible was placed in a radio frequency furnace and the sample combusted in a stream of carbon dioxide-free oxygen. Gases generated by the combustion process were passed through a series of catalysts, to ensure complete oxidation, and scrubbers, to remove components that would interfere with the $\mathrm{CO}_{2}$ measurement. The $\mathrm{CO}_{2}$ was then absorbed onto molecular sieve at room temperature. When sample combustion and $\mathrm{CO}_{2}$ collection were complete the molecular sieve was heated to 350

${ }^{\mathrm{o}} \mathrm{C}$, releasing the absorbed $\mathrm{CO}_{2}$, and the $\mathrm{CO}_{2}$ measured using a thermal conductivity detector.

The Fisons NA1500 EA/Optima IRMS was used to determine total carbon, total nitrogen; ${ }^{13} \mathrm{C}$ and ${ }^{15} \mathrm{~N}$ employed a Fisons NA1500 elemental analyser for sample combustion and separation of $\mathrm{CO}_{2}$ and $\mathrm{N}_{2}$ from other combustion products. The gas stream from the elemental analyser then entered the Optima IRMS which was used to obtain analytical data for total carbon, total nitrogen, ${ }^{13} \mathrm{C}$ and ${ }^{15} \mathrm{~N}$. For this analysis between 1 and $30 \mathrm{mg}$ of sample, depending on the estimated carbon concentration, was loaded into a tin capsule and the capsule tightly crimped to exclude atmospheric gases. Samples were then combusted at $1000{ }^{\circ} \mathrm{C}$ in a stream of oxygen. The gases generated during combustion then pass through heated combustion and reduction reactors to achieve quantitative conversion of carbon and nitrogen from the sample to $\mathrm{CO}_{2}$ and nitrogen $\left(\mathrm{N}_{2}\right)$. The combustion products next passed through a chromatographic column where $\mathrm{CO}_{2}$ and $\mathrm{N}_{2}$ were separated and then introduced into the mass spectrometer for measurement. Elemental concentrations were calculated 
USGS MBCP-U Document text

based on instrument responses for calibration standards. Isotope ratio measurements were corrected for fractionation effects and calibrated based on materials with known values.

In the early stages of this study, the Fisons NA1500 EA/Optima IRMS was used only to obtain total nitrogen and ${ }^{15} \mathrm{~N}$ data. However, total carbon data for samples analyzed using the LECO instrument, and ${ }^{13} \mathrm{C}$ data for samples analyzed in a conventional extraction line/mass spectrometer lab, showed close agreement with data for the same samples analyzed using the EA/IRMS instrument (data not shown). As a result of this data comparison the EA/IRMS was used for nearly all TC, IC, ${ }^{13} \mathrm{C}$, and ${ }^{15} \mathrm{~N}$ analyses performed on solid samples.

In addition to calibration materials, three standard materials were routinely included in all EA/IRMS sample runs. These materials were a well analyzed sample of ethylenediaminetetracetic acid (EDTA) obtained from Fisons Instruments, S.p.a., a marine sediment (MESS-1) issued by the Chemistry Division of the Canadian National Research Council and a river sediment (NBS1645) issued by the National Bureau of Standards, now known as National Institute of Standards and Technology. Precision estimates, expressed as relative standard deviation, were 3.6-6.5percent for total carbon, 3.7-6.5 percent for total nitrogen, 1.4-2.9 percent for ${ }^{13} \mathrm{C}$, and 20-47 percent for ${ }^{15} \mathrm{~N}$, based on results for the standard materials (table below). Approximately 3percent of all samples were also analyzed in duplicate. For these duplicate runs the range, expressed as a percentage of the average of the duplicate runs, was less than 1percent for total carbon, less than 2 percent for total nitrogen, less than 1 percent for ${ }^{13} \mathrm{C}$ and about 15 percent for ${ }^{15} \mathrm{~N}$.

\begin{tabular}{|l|c|c|c|c|}
\hline \multicolumn{1}{|c|}{ I.D. } & total $\%$ total $\% \mathrm{~N}$ & delta $13 \mathrm{C}$ & delta $15 \mathrm{~N}$ \\
\hline & $(\%$ rsd $)$ & $(\%$ rsd $)$ & $(\%$ rsd $)$ & $(\%$ rsd $)$ \\
\hline EDTA & 3.6 & 3.7 & 1.5 & --- \\
\hline MESS-1 & 4 & 3.9 & 2.9 & 20.1 \\
\hline NBS-1645 & 6.5 & 6.5 & 1.4 & 47.2 \\
\hline
\end{tabular}

Inorganic carbon was determined by measuring the $\mathrm{CO}_{2}$ generated by treating approximately $100 \mathrm{mg}$ of sample with $2 \mathrm{~N}$ perchloric acid $\left(\mathrm{HClO}_{4}\right)$ and heating the mixture at $105{ }^{\mathrm{O}} \mathrm{C}$. The evolved gases were first passed through an acidic $(\mathrm{pH} 3)$ saturated silver sulfate $\left(\mathrm{Ag}_{2} \mathrm{SO}_{4}\right)$ solution containing 3percent hydrogen peroxide $\left(\mathrm{H}_{2} \mathrm{O}_{2}\right)$ to remove contaminants and then were bubbled through a partially aqueous solution containing ethanolamine and a colorimetric indicator. The $\mathrm{CO}_{2}$ was quantitatively absorbed and converted to a strong, titratable acid by the ethanolamine. The amount of $\mathrm{CO}_{2}$ evolved from the sample was measured by integrating the amount of current required to electrically generate enough base to titrate the acid.

The uncertainty in the IC determinations, expressed as relative standard deviation, is approximately 5 percent when IC is present. The range of IC values for standard materials run in duplicate was less than one percent of the carbon value. 


\subsection{RADIOCARBON}

The ${ }^{14} \mathrm{C}$ content of the solid and gas phases of soil is used to calculate overall turnover time or to partition the organic carbon into more labile or stable pools. Radiocarbon content of ground, untreated soil was measured by sealing enough homogenized sample to make $\sim 1 \mathrm{mg}$ of $\mathrm{C}$ with cupric oxide wire and a small piece of silver wire in an evacuated, quartz tube. The $\mathrm{CO}_{2}$ produced is purified cryogenically and then reduced to graphite using a zinc- or iron-catalyzed reduction method

described in Vogel (1984). . The ratio of ${ }^{14} \mathrm{C}$ to ${ }^{13} \mathrm{C}$ and ${ }^{12} \mathrm{C}$ atoms is measured directly from the graphite target using a high energy accelerator as an inlet to a mass spectrometer (AMS).

We express ${ }^{14} \mathrm{C}$ data in the geochemical Delta notation (Delta $=$ capitol greek delta), the deviation in parts per thousand (per mil) from an absolute standard .(95 times the activity of NBS oxalic acid measured in 1950). We also note the ratio of ${ }^{14} \mathrm{C} /{ }^{12} \mathrm{C}$, referred to as Fraction Modern notation. In calculating the Delta ${ }^{14} \mathrm{C}$ or Fraction Modern, we correct for isotopic fractionation effects that occur as a result of photosynthesis (the origin of soil organic matter) by correcting both sample and standard to a measured ${ }^{13} \mathrm{C}$ value of the same sample. If ${ }^{13} \mathrm{C}$ was not measured on the sample, then we correct using a value -25 per mil (as noted in parentheses in tables). The standard oxalic acid is corrected in the same way, to -19 per mil.

\subsection{PARTICLE SIZE ANALYSIS}

Samples were selected to characterize particle-size distribution of soils. Based on limited sample sizes, not all soil horizons and not all sites were fully characterized for particle size. Two preparations, conventional dispersal and water-based dispersal, were used to characterize sand, silt and clay particles.

Conventional dispersal of soil samples is based on the principal that soil particles aggegate to form coarser particles and must be dispersed chemically or physically. Sodium hydroxide, sodium hexametaphosphate, and citrate-bicarbonate were used for dispersal according to methods of Gee and Bauder (1986, p400-401), and samples were sieved (Gee and Bauder, p 401) and analysed by pipet (Gee and Bauder, p. 401-402) for determination of USDA sizes for sand (>0.05mm or 50 micrometer), coarse silt ( 0.02 to $0.05 \mathrm{~mm}$ or 20 to 50 micrometer), fine silt ( 0.002 to $0.02 \mathrm{~mm}$ or 2 to 20 micrometer), and clay $(<0.002 \mathrm{~mm}$ or $<2$ micrometer) fractions. For water-based dispersal, no pretreatment was used before sieving and pipet analysis.

\section{$2.6{ }^{10} \mathrm{Be}$ ANALYSIS}

For ${ }^{10} \mathrm{Be}$ analysis, bulk soil is decomposed by $\mathrm{HClO}_{4}+\mathrm{HF}+\mathrm{HCl}$ and dried. The dried solid cake is extracted by $3 \mathrm{~N} \mathrm{HCl}$ and precipitated by $\mathrm{NH}_{4} \mathrm{OH}$ to form $\mathrm{Fe}(\mathrm{OH})_{3}$. The precipitate is dissolved by $10 \% \mathrm{HF}$ and re-precipitated to $\mathrm{Fe}(\mathrm{OH})_{3}$ by $\mathrm{NH}_{4} \mathrm{OH}$, while Be complex ion is formed in solution. The solution is dried at $250 \mathrm{deg} \mathrm{C}$, treated with $\mathrm{HCL}$ and $\mathrm{NH}_{4} \mathrm{OH}$ to form $\mathrm{Be}(\mathrm{OH})_{2}$, baked again at $550 \mathrm{deg} \mathrm{C}$ for a $\mathrm{BeO}$ target for accelerator mass spectrometry at the Lawrence Livermore 


\section{USGS MBCP-U Document text}

Laboratory. This method was developed by Fouad Tera of the Canegie Institution in Washington D.C.

\subsection{DATA-SET IDENTIFICATION}

The data presented represent sampling from the fall of 1996 to the fall of 1997 . The MBCPIAUpland Soils Database is structured as a set of tables in both Microsoft Access (_mdb) files and as tab-delimited ASCII (_rdb) files. Records in each of the four types of files (Iowa _Site, Iowa _Field, Iowa_Soil, Iowa_Isotope, Iowa_Psize) form a unique file that relate on the fields PROFILE and DEPTH. Four data sets are included for Iowa sites:

$\begin{array}{ll}\text { Iowa_Site } & \text { (Site Location and Explanation) } \\ \text { Iowa_Field } & \text { (Field Descriptions of Soils) } \\ \text { Iowa_Soil } & \text { (Chemical, Physical, Isotopic Data from Soils) } \\ \text { Iowa_Isotope } & \text { (Radiocarbon of Soil and Soil Gas) } \\ \text { Iowa_Psize } & \text { (Particle Size Analysis of Soils) } \\ \text { Iowa_10Be } & \text { (Be Isotope Analysis of Bulk Soil) }\end{array}$

The "Iowa_site" file includes site locations and explanations of sites. All other files use site codes described in the Iowa_Site file.

The "Iowa_Field" files include those properties described by USDA for field characterization and classification. (USDA, 1987).

The " Iowa_Soil" file includes solid phase analyses of bulk soil samples.

The " Iowa_C_Isotope" file includes radiocarbon analyses on solid and gas-phase samples.

The " Iowa_Psize" file includes particle size analysis data.

The "Iowa_10Be" file contains Be analyses of bulk soil samples.

\subsection{LABELING SCHEMES}

The overall strategy for labling samples is designed for replicate measurements at each ridge, upper (erosional) and lower (depositional) hillslope position at each site, for example at the Dinesen Prairie Upper slope. Replicate profiles are numbered consecutively, for example DPU1 through 3. Soil samples were collected in depth increments (soil horizons) in a vertical array at each site replicate. A decimal is used to designate basal depth (in $\mathrm{cm}$ ) of the sample and is placed to the right of the decimal point, for example TRPU1.20 for $20 \mathrm{~cm}$ basal depth or TRPU1.200 for $200 \mathrm{~cm}$ basal depth. In some cases, lower case letters are used to indicate the intended purpose of the sample at the time of collection, including $\mathrm{a}, \mathrm{b}, \mathrm{m}, \mathrm{f}$, and $\mathrm{i}$ for analytical, bulk density, moisture content, fractionation, incubation samples respectively, for example TRPU1.20a,b,m. In other cases, replicate samples are indicated by a lower case to the left of the decimal, for example TRPU1a, TRPU1b. 


\subsection{DATA SET DESCRIPTIONS}

Six categories of data sets are presented, including site and location data (Iowa_Site), field data (Iowa_Field), soil analytical data (Iowa_Soil), soil isotopic data (Iowa _Isotope), particle size data (Iowa_Psize) and 10Be data (Iowa_10Be). Column headings and units for each of these data sets are described herein:

3.21 IOWA_SITE FILES contain the following information in text format

Site location, slope description, landuse notes, date of sampling, purpose of sampling, field personnel.

3.22 IOWA_FIELD FILES contain the following information in column format

PROFILE is keyed to the Iowa_Site file for location and site information

DEPTH indicates the basal depth in $\mathrm{cm}$ of sampling increment

HORIZON includes a general description of the sampled horizon (A horizon, oxidized B horizon, etc.) (see Soil Survey Staff, 1981).

MCOLOR includes moist soil color using the Munsell soil color chart

STRUCTURE includes classes of size, strength and type of soil structure following conventions of Soil Survey Staff (1981)

TEXTURE includes soil texture class following conventions of Soil Survey Staff (1981)

PLASTICITY includes wet consistence class following conventions of Soil Survey Staff (1981)

STICKINESS includes wet consistence class following conventions of Soil Survey Staff (1981)

FIRMNESS includes moist consistence following conventions of Soil Survey Staff (1981)

ROOTS includes root abundance and size classes following conventions of Soil Survey Staff (1981)

3.23 IOWA_SOIL FILES contain analytical data on the solid phase of soil samples, using numbers assigned in the _Site file and the labling scheme described above.

PROFILE refers to the profile number in the Iowa_Site file for information regarding location and sampling conditions.

DEPTH is the depth in $\mathrm{cm}$ of the base of the soil horizon sample; the top depth is generally the basal depth of the superjacent soil horizon.

AIRDRYM is the airdry soil moisture is reported as the gravimetric moisture content (grams water per gram oven-dry soil) and can be used to convert other data to the oven-dry basis : WW = $\mathrm{DW} /(1+\mathrm{DW})$ and $\mathrm{DW}=\mathrm{WW} /(1-\mathrm{WW})$, where DW is water content on the dry-weight basis, and WW is water content on the wet-weight basis (Gardner, 1986, p493-541). Using this 


\section{USGS MBCP-U Document text}

relationship, \%C or Bulk Density, which are reported per g air-dry soil, can be converted to the more conventional per g oven-dry basis using the formula:

$\% \mathrm{C}($ air dry basis $) * \mathrm{WW} /(1-\mathrm{WW})=\% \mathrm{C}$ (oven-dry basis)

TOTALC1 is total carbon determined by Leco combustion analyser and is expressed as gravimetric percent on an air-dry soil basis. Samples were analyzed on the $<2 \mathrm{~mm}$ soil on a LECO combustion analyser.

TOTALC2 is total carbon expressed as gravimetric percent on an air-dry soil basis. Samples were analyzed on the $<2 \mathrm{~mm}$ soil fractions (once homogenized and ground to $<60 \mathrm{mesh}$ ) on a Fisons NA1500 elemental analyser.

INORGANICC is carbonate carbon determined by acid treatment and UIC coulometer and is reported as $\% \mathrm{C}$ on air-dry basis.

ORGANICC is the difference between TotalC2 and InorganicC and is expressed as \%C on air-dry basis.

BD is bulk density as g of air-dry soil per cubic $\mathrm{cm}$ of soil. Conversion to oven-dry basis is described in AIRDRYMoisture

TOTALN total $\mathrm{N}$ content is expressed as gravimetric percent of air-dry soil

SOILC13 stable isotope ${ }^{13} \mathrm{C}$ content of the $<2 \mathrm{~mm}$ (bulk) soil is presented in Delta notation using per mil units

SOILN15 stable isotope $15 \mathrm{~N}$ content of the $<2 \mathrm{~mm}$ (bulk) soil is presented in Delta notation

CDENSITY carbon density is calculated from TOTALC2 $*$ BD

CSTORAGE carbon storage is calculated from TOTALC $2 * \mathrm{BD} *$ thickness of sample as basal depth minus basal depth of superjacent horizon.

3. 24 Iowa _Isotope files contain the ${ }^{14} \mathrm{C}$ analyses for solid and chamber gas samples.

PROFILE is the profile number that keys back to Iowa_Site files

SAMPLE sample identification keys back to _Site files

DEPTH indicates depth of sample; NA not applicable usually refers to chamber samples collected at the soil surface

LABID is the laboratory identification number used by University of California Irvine and Lawrence

Livermore Laboratories

TYPE sample type analysed

DEL ${ }^{13} \mathrm{C}$ values for Delta ${ }^{13} \mathrm{C}$

DEL ${ }^{14}$ Cvalues for Delta ${ }^{14} \mathrm{C}$

LABSD values for error in radiocarbon counting 


\section{USGS MBCP-U Document text}

3.25 IOWA_PSIZE files contain the following information in column format

SampleID sample identification keys back to the IOWA_SITE files

USDASAND standard dispersant, percent by weight of particles greater than 50 micrometer in size

USDACOSI standard dispersant, percent by weight of particles between 20 and 50 micrometers in size

USDAFISI standard dispersant, percent by weight of particles between 2 and 20 micrometers in size

USDACL standard dispersant, percent by weight of particles less than 2 micrometers in size

WSAND water dispersant, percent by weight of particles greater than 50 micrometer in size

WCOSI water dispersant, percent by weight of particles between 20 and 50 micrometers in size

WFISI water dispersant, percent by weight of particles between 2 and 20 micrometers in size

WCLAY Water dispersant, percent by weight of particles less than 2 micrometers in size

3.26 IOWA_BE10 files contain ${ }^{10}$ Be isotopic data for solid phase samples.

PROFILE is the profile number that keys back to Iowa_Site files

DEPTH indicates depth of sample; NA not applicable usually refers to chamber samples collected at the soil surface

$10 \mathrm{Be} 10^{8}$ atom/g indicates the number of ${ }^{10} \mathrm{Be}$ atoms per $\mathrm{g}$ of sample

4.00 Application of the Data Set

The main purpose of the data set is to gain insight into the interaction between the carbon cycle and erosion-sedimentation cycle (see Harden et al, 1999). The data sets are best suited to address $\mathrm{C}$ and sedimentation processes on small hillslopes, with applications to land-atmosphere exchange of carbon, surface water chemistry, and watershed modelling.

Our sampling strategy allows several types of comparative analyses that can be used to test hypotheses or modeling scenarios. (1) Soil properties across a hillslope gradient can be assessed by comparing ridge ( $\mathrm{R}$ ), upper eroding midslope $(\mathrm{U})$ and lower depositional slope (L) positions. Particle size and ${ }^{10} \mathrm{Be}$ isotopes allow an evaluation of particle sorting as a function of slope distance (Rosenbloom et al, 2000) or the balance between loess accumulation and hillslope degradation during soil development (Harden et al, submitted). This comparison can be applied to each a hillslope in a native prairie and an hillslope in an agricultural cropland. (2) Comparisons can also be made between the prairie and cropland for analysis of changes in landuse or as a "space for time substitute" in which the prairie site represents soils in their native, pre-agricultural state and the cropland represents soils as they exist throughout the midwest today (with the exception of course of small remnant preserves) (Harden et al, 1999). (3) Comparisons can be made among samples collected in a time series from May 1997 to November 1999, when the Treynor site was converted from a longstanding corn field under conventional tillage (see Manies et al, 2000) to a soybean field under no-till (drilled) methods. This time series records the isotopic shift in ${ }^{13} \mathrm{C}$ of soil organic matter that results from the 
USGS MBCP-U Document text

conversion of corn to soybean, which in turn can facilitate estimates of soil carbon turnover (ref). (4) For carbon cycle and radiocarbon studies and models, basic variables and equations can be applied or tested with these data. For example, turnover times for soil carbon can be constrained somewhat by the ${ }^{14} \mathrm{C}$ content of soil gas and bulk soil, as described by Trumbore 1996. The interaction among plant input, decomposition, and erosion can be studied with more robust data (Harden et al, 1999).

(5) Last, information on the fate of carbon in deep sediment can be addressed through ${ }^{10} \mathrm{Be}$ and ${ }^{14} \mathrm{C}$ data of the deep samples (see Harden et al, submitted).

\section{00 References}

Bettis III, E.A., 1990, Holocene alluvial stratigraphy of western Iowa IN Holocene alluvial stratigraphy and selected aspects of the Quaternary history of western Iowa - Midwest Friends of the Pleistocene $37^{\text {th }}$ Field Conference, Council Bluffs, Iowa, May 12-13, 1990: Iowa Quaternary Studies Group Contribution No. 36, pp 1-16.

Collins, H.P., Paul, E.A., Paustian, K. and Elliott, E.T., 1997. Characterization of soil organic carbon relative to its stability and turnover. IN Paul, EA, Elliott, E.T., Paustian, K, and Cole, C.V., Soil organic matter in temperate agroecosystems. CRC press, New York. p. 51-72.

Dabney, S. M., C.E., M., Meyer, L. D., Grissinger, E. H., Harmon, W. C., \& Triplett, G.

B.,1997. Runoff and sediment yield from conventional and conservation cropping systems IN Wang, S.Y., E.J. LangendoenF.D. Shields, Jr., Management of Landscapes Disturbed by Channel Incision, Conference Procdeedings, Oxford, Miss. p983-989.

Davidson, E. A., \& Ackerman, I. L., 1993. Changes in soil carbon inventories following cultivation of previously untilled soils. Biogeochem, 20, 161-193.

Gardner, W.H. 1986. Water Content IN Klute, A.K. (ed) Methods of soil analysis part 1, physcial and mineralogical methods, $2^{\text {nd }}$ Ed. Amer. Soc. Agronomy and Soil Sci Soc. Amer. Agronomy Series 9 .

Gee, G.W. and Bauder, J.W. 1986, Particle size Analysis IN Klute, A.K. (ed) Methods of soil analysis part 1, physcial and mineralogical methods, $2^{\text {nd }}$ Ed. Amer. Soc. Agronomy and Soil Sci Soc. Amer. Agronomy Series 9.

Harden, J.W., Fries, T., and Huntington, T. Mississippi Basin Carbon Project - Upland Soil Database for Northwestern Mississippi, 1998, U.S. Geological Survey Open-file Report 98-440. 
Harden, J. W., Sharpe, J. M., Parton,W. J., Ojima, D. S., Fries, T. L., Huntington, T. G. and Dabney , S. M., 1999. Dynamic replacement and loss of soil carbon on eroding cropland. Global Biogeochemical Cycles 13, No. 04, p. 885-903.

Harden, J.W., T. Fries, M. Pavich, in press. Evolution of Hillslopes in Iowa and Implications for Carbon Cycling. Submitted to Biogeochmistry.

Houghton, R. A., Hobbie, J. E., Melillo, J. M., Moore, B., Peterson, B. J., Shaver, G. R., \& Woodwell, G. M., 1983, Changes in the Carbon Content of Terrestrial Biota and Soils Betwen 1860 and 1980: A Net Release of $\mathrm{CO}_{2}$ to the Atmosphere. Ecological Monographs, 53, 235-262.

Huntington, T.G., Harden, J. W.,Dabney, S. M. , Marion, D. A. , Alonso, C. , Sharpe, J.M. , 1998, Soil, Environmental, and Watershed Measurements in support of carbon cycling studies in northwestern Mississippi. U.S. Geological Survey Open-File Report 98-501.

Lal, R., Kimble, J., Levine, E.,and Stewart, B. A. (Ed.)., 1995, Global soil carbon resources. Boca Ratan: CRC, Inc.

Manies, K. L, Harden, J.W., Kramer, L. and Parton, W. 2000, Parameterizing Century to model cultivated and noncultivated sites in the loess region of western Iowa. U.S. Geological Survey Openfile Report 00-508, 30p.

Manies, K.L., Harden, J.W., Kramer, L., and Parton, W.J. in press. Carbon dynamics within agricultural and native sites in the loess region of western Iowa. Global Change Biology.

Mann, L. K. , 1985, A regional comparison of carbon in cultivated and uncultivated Alfisols and Mollisols in the central United States. Geoderma, 36, 241-253.

McGregor, K. C., Greer, J. D., Gurley, G. E., \& Bolton, G. C.,1969. Runoff and sediment production from North Mississippi loessial soils . USDA Agric. Exp. Sta. Bulletin No. 777.

Muhs, D. and A.Bettis III, 2000. Geochemical Variations in Peoria Loess of Western Iowa Indicate Paleowinds of Midcontinental North America during Last Glaciation. Quaternary Research 53: 49-61.

Parton, W. J., Schimel, D.S., Cole, C.V., Ojima, D.S. 1987. Analysis of factors controlling soil organic matter levels in Great Plains grasslands. Soil Sci. Sco. Amer. Jour. 51, p1173-1179. 
Rhoton, F.E. 1990, Soybean yield response to various depths of erosion on a fragipan soil. Soil Sci. Soc. Amer. Jour. 1073-1079.

Rosenbloom NA, Doney SC, \& Schimel DS (in press). Geomorphic evolution of soil texture and organic matter in eroding landscapes. Global Biogeochemical Cycles.

Schimel, D. S. (1995). Terrestrial ecosystems and the carbon cycle. Global Change Biology, 1.

Soil Survey Staff, 1951, Soil Survey Manual, U.S. Dept. Agric. Handbook no 18; 503 pages.

Stallard R.F., 1998, Terrestrial sedimentation and the carbon cycle: coupling weathering and erosion to carbon burial. Global Biogeochem. Cycles 12: 231-257.

Sundquist, E.T., Bliss, N.B., Dean, W.D., Harden, J.W., Pavich, M.J., Markewich, H.W., and Stallard, R.F. 1998. U.S. Geological Survey Mississippi Basin Carbon Project Science Plan. U.S. Geological Survey Open-file report 97-3852. 28p.

Trumbore, S. E.,1996. Measurement of cosmogenic isotopes by accelerator mass spectrometry: applications to soil science IN Boutton, T. and Yamasaki, S., Mass Spectrometry of Soils. Marcel Dekker, New York.

Vogel, J.S., Southon, J.R., Nelson, D.E. and Brown, T.A., 1984, Performance of catalytically condensed carbon for use in AMS. Nuclear Instruments and Methods 85, 284-293.

For information on sampling strategy, sample submittal, soil characterization/description, analytical data, and isotopic data, and modeling please contact:

Jennifer Harden

USGeological Survey

345 Middlefield Rd. MS 962

Menlo Park, CA 94025

650-329-4949

jharden@usgs.gov

For information on soil analysis or analytical methods please contact:

Terry Fries

USGeological Survey

345 Middlefield Rd. MS 962

Menlo Park, CA 94025 
$650-329-5281$

For information on site history and agricultural practices as DLRS please contact:

Larry Kramer

National Tilth Laboratoratory

Agricultural Research Service

Council Bluffs, IA 51503

For information on radiocarbon and Be methodologies please contact:

Shuhui Zheng

Dept. Earth System Science

University of California

Irvine, CA 92697-3100

\section{00 Acknowledgements}

USDA-ARS Many thanks to Lori Keith, Kristen Manies, and Gary Buell for help with field sampling; Tom Huntington for planning and field support; Doug White and Susan Trumbore for isotope analysis; Tom Fenton for sample archives and for all particle size analyses; and Helaine Markewich and Milan Pavich for programmatic support. 